\title{
CXXC-Type Zinc Finger Protein 5
}

National Cancer Institute

\section{Source}

National Cancer Institute. CXXC-Type Zinc Finger Protein 5. NCI Thesaurus. Code C152032.

CXXC-type zinc finger protein 5 (322 aa, $\sim 33 \mathrm{kDa}$ ) is encoded by the human CXXC5 gene. This protein plays a role in transcriptional regulation. 